\title{
By Canoe and Speedboat: The Recent Expansion of the Illàjẹ Fishing Trade
}

\author{
Kayọde Joseph Onipede ${ }^{1}$ \\ Ladoke Akintola University of Technology Ogbomọṣo, Nigeria \\ Kayodeonipede2004@yahoo.co.uk
}

\begin{abstract}
Competition has remained a significant feature of trade, particularly in regions with diverse social groups like the Niger Delta region of Nigeria. This article examines the expansion of trade among the İlàjẹ communities of Òndó State in the coastal area of Yorùbáland, which to the best of our knowledge has not been documented. Historical method of data collection and analysis were employed in the study. These include primary and secondary sources. The primary sources are mainly comprised of interviews of key informants and participants' observations. The secondary sources consist of journal articles and texts. The results were analyzed qualitatively.

The growth in coastal trade in the İlàje area from 2010 onwards was largely due to the construction of new roads along the coast, which linked İlàje to the wider road network. Between 2009 and 2013, new trading routes emerged along the road from İgbọ́kọ̣dá to Arárọ̀mi via Atíjẹerẹ́ on the western side to Ògun and Lagos state, passing through towns like Ipárè, Oko-Ńlá, Òbínẹ́hìn, Etíkàn, Erékè, and Àbòtó. Another route linked İgbọ́kọ̀dá with Òde-Ùgbò and Ùgbò-Ńlá coastal market in the east. As traders and goods came into İlàje from various parts of Nigeria, new markets sprang up to facilitate the exchange
\end{abstract}

1. The author appreciates the contributions of the following people in the process of collecting data for the study. Mrs Oke, Chief (Mrs) Akinyomi (İyálọjà of İgbọ́kọ̀dá Market), Mr and Mrs Abilogun and Family in İgbọ́kọ̀dá, Miss Janet Abilogun and Tunde Abilogun my anchors from İgbọ́kọddá to Òkè-ìdí Ògbá. Mr Adeogo Akintola, Mr Banjo Omoboye and Mr. Abilogun Jnr for providing information of the fishing economy, The Bàbálọjà and İyálọjà of Òbínệhin market, $\mathrm{Mr}$ and Mrs Adeha and the Secretary of Òbínẹhìn main market, $\mathrm{Mr}$ Akingboye Lohan and Baba Òyìnbó, the Bàbálọjà of Òde-Ügbò market for providing informations on new markets in Ilaje. 


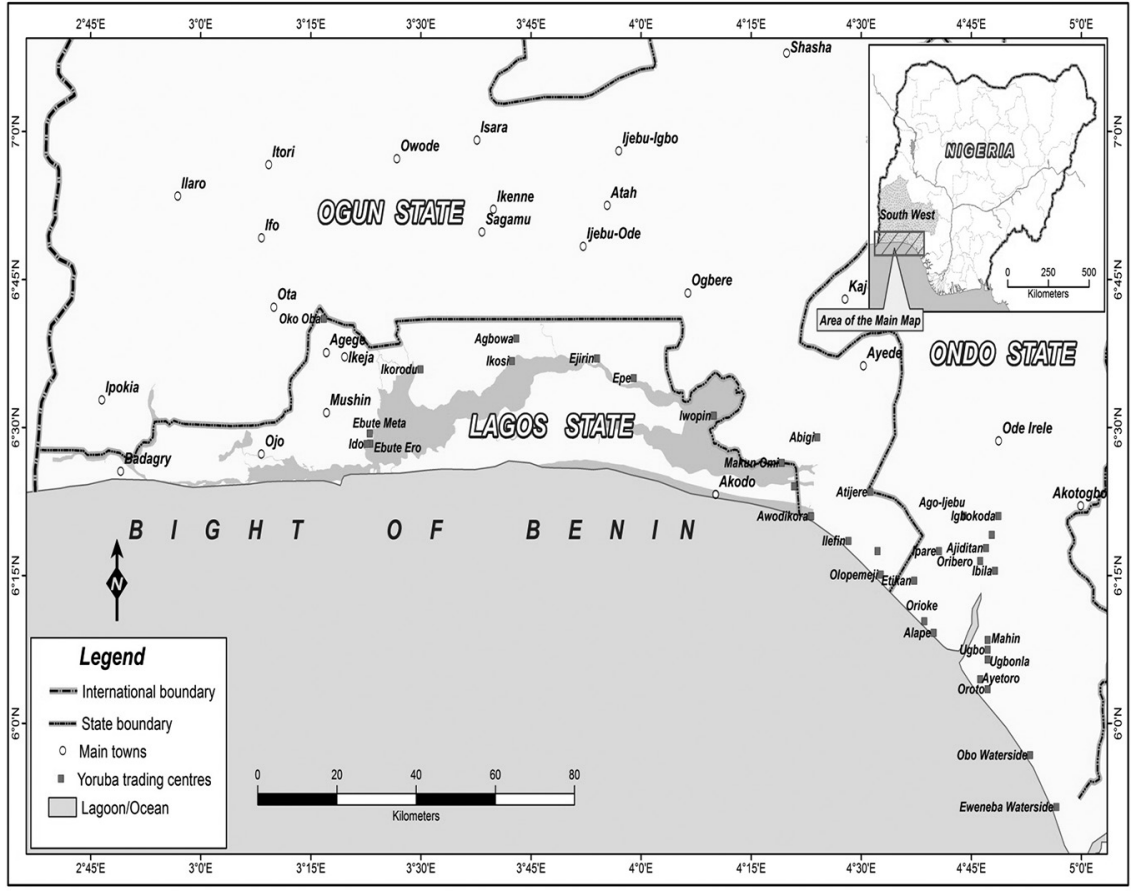

Figure 1. Map of Yorùbá Coastal Communities Showing the Studied Area. Source: Department of Geography, Faculty of Social Science, University of Ibadan.

of upland goods for fish products. The construction of new roads also encouraged social and economic development by bringing into the area goods and commodities hitherto not transportable on water, such as 'modern' building materials. However, far from reducing water-based activity, the overall increase in trade has also contributed to an increase of water-based traffic, especially for fishing.

\section{Introduction}

Formerly important trading towns on the local caravan trade routes [when] bypassed by modern lines of communication ... declined as trading centers ${ }^{2}$

2. Hodder and Ukwu in 1969, quoted in O. O. Olubomehin, "Road transportation as lifeline of the economy in Western Nigeria 1920-1952," African Journal of History and Culture, 4.3 (2012): 37-45. 
As this quote shows, many scholars emphasize the relative decline in Nigeria's coastal trade compared to overland trade by railway or road in the second decades of the twentieth century. This, however, does not mean that the absolute importance of water-based trade declined. As many coastal Yorùbá settlements were not linked up to the road network until the twenty-first century, the growing population of these communities contributed to the trade in a range of goods, including fish, both along the coast and lagoon and uplands from the major harbor towns.

Studies on the coastal regions of Nigeria have noted the contribution of the lagoon trade to Nigeria's economy up to the twentieth century. While many have highlighted the contribution of the fish trade to the coastal economy, Olúkòjú has also explained how this was linked to population movements and socio-economic interactions within and across the coastal belt over the past millennium. He explained the intense struggle and competition for fish markets that dovetail with the quest for wider markets for maritime products that also resulted in inter-group relations. As the İlàjẹ ideological and religious orientation supported inter-group relations in a particular ways, it also led to the convergence of new maritime towns from the late 1940s onwards, including Ayétòrò, Ùgbò-Ńlá, Zion Pẹpẹ̀, and Oríòè-İwàmímọ́, all of which participated in the fishing trade on the İlàjẹ coastline. ${ }^{3}$

This article takes Olúkòjú's argument further into the present and examines the expansion of İlàjẹ trade in recent times, as both a significant contribution of the coastal region of Yorùbáland and to Nigerian economic development more generally. The article's focus on the recent expansion of trade, and the description of the emergence of new markets, fill a gap in historical scholarship and humanistic studies. The article is divided into five sections: the first section offers a background of Ìlàje history, the second looks at the patterns of İlàjẹ trade in the nineteenth and twentieth century, the third discusses the rise of new markets and trade routes, the fourth discusses the new İlàje fishing economy and trade, and the last is the conclusion.

\section{Patterns of ìlàjẹ trade in the 19th and 20th century}

The İlàjẹ people occupy the İlàjẹ Local Government Area and lay between $4^{\circ} 50^{\prime}$ and $5^{\circ} 15^{\prime} \mathrm{E}$ and $6^{\circ} 00^{\prime}$ and $6^{\circ} 25^{\prime} \mathrm{N}$. İlàjẹ country is bounded by İjẹbú to

3. A. Olukoju, "Fishing, Migration and Intergroup Relations in the Gulf of Guinea (Atlantic Coast of West Africa) in the Nineteenth and Twentieth Centuries," Itinerario: European Journal of Overseas History, 24.1 (2000): 69-85.

4. Adeparusi, Ajibefun and Akeremale, "Profit efficiency in fish smoking in Ilaje Local Government Area of Òndó State, Nigeria," International Journal of Agriculture and Food Security, 4.1\&2 (2013): 421-427. 
the west, İkálè to the north, Àpọ́i and Àrògbò Ijaw to the north east, Itsekiri to the east, and the Atlantic Ocean to the south. The İlàje people are spread over four hundred communities that are historically divided into four kingdoms, namely Òde Ügbò, Òde Màhin, Ode Etíkàn, and Àhérì, all settled along the coastline. ${ }^{5}$ These four kingdoms claim Yorùbá origin from Ilé-Ifẹ̀. Akinjọggbìn and Àyándélé linked the time of their departure from Ife to the beginning of Odùduwà dynasty. However, there are other migrant settlers on the lagoon from areas as far as Àkókó, İbàdàn and Calabar that have been incorporated into the fishing trade. ${ }^{6}$

The İlàje part of Òndó-state and is composed of several fishing communities located within the river tributaries discharging into the Atlantic and along the coastline. The Îlàje are believed to have the longest coastline in Nigeria, measuring about $78 \mathrm{~km}$. Akegbejo Samson noted about 80 communities along the coastline, whose inhabitants are mostly engaging in fishing and the fish trade. Fishing, trade, and the availability of unclaimed land, but also environmental changes, such as oil pollution in parts of the lagoon waters, have encouraged population movement from the more inland İlàje communities towards the coastline. However, numerous rivers and canals enable easy communication between coastal and inland communities by canoe or speedboat, which until recently remained the main means of local transportation.

Among the diverse population exploiting the lagoon and coastal environment, the main routes of trading, migration as well as social and political relationships were the waterways, and transportation was by canoe. ${ }^{7}$ Since the only means of transportation was the canoe, which relied on the water ways from the coast to the hinterland, İlàjẹ social and economic development relied on accessibility by canoe. Due to their location on often sandy and poor soil, İlàjẹ settlements were difficult to sustain by agricultural production alone. Hence, they have a long history of artisanal fishing, and obtain many goods through exchange for fish and other sea products like shrimps, crayfish, prawns, crabs, and snails. These different types of water-grown protein have helped to develop the people beyond the subsistence economic level and also form the basis of interaction between the İlàje and their neighbors.

5. S. Akegbejo, "Ecology of the fisheries resources of coastal wetlands of Òndó state and its management Implications," (PhD thesis, Federal University of Technology, Àkúrẹ, 1995), 1-297.

6. This information was given by some of my informants who claimed their father or grandfather migrated from İbàdàn, Àkókó and other Yorùbá towns.

7. Edith Osiruemu, "Water transportation in the Niger Delta, c. 1500-1900", in A. Ogundiran, ed., Precolonial Nigeria Essays, in Honor of Toyin Falola (New Jersey: Africa World Press, 2005), 411-424. 
Studies of the patterns of trade in pre-colonial Nigeria reveal that economic production was geared not only towards immediate domestic needs, but also to the facilitation of external trade. Lively trading relations, where they existed, often also facilitated the movement of people and their practices from one region to the other. ${ }^{8}$ The İlàje people, located in the agriculturally poor but fishrich eastern Delta, exchanged fish for agricultural products from the adjoining communities, including the Ijệbú in the west, the Ijaw in the north and the İkálẹ in the east, which supply most of the food items like cassava (gàrí), yam, plantain, and palm oil. Moreover, the Ijaw areas also provided canoes and timber from the mangrove forest. ${ }^{9}$ In other words, there was a well-established south-north and westward commercial trade between the İlàjẹ and their İlàjẹ, Àpọi and Ijaw neighbors, which also facilitated a westward commercial transaction between the İlàjẹ and the İjẹbú port of Ejìnrìn, which in the eighteenth and nineteenth century facilitated much trade towards Lagos through the canoe system.

Commenting on trade in Yorùbá coastal areas after the abolition of slave trade, Adéùyán explains that in addition to spirits, gin and gun powder, European goods like buckets, house utensils and chinaware were traded in Yorùbá coastal markets. He noted that the imported gin, or trade spirit, had no match for the locally manufactured Ògógóró. ${ }^{10}$ Oguntomisin states that palm products exported by İlàjẹ people at Atíjẹreẹ, Àbòtó, and Àrògbò markets were transported by canoe to markets in Ejìnrìn, İtọíkín and İkòròdú, and also to Orímẹ́dù and Lékè [Lekki] for sale to the Europeans. ${ }^{11}$ In İlàjẹ, trade by canoe can be undertaken by male and female members of the community. Trade across the lagoon or along the coast took individual traders as far as Gabon, Cotonou, Togo, and Ghana. ${ }^{12}$

However, due to the largely informal nature of the trade, and the existence of many smaller ports and markets in addition to those where available documents and reports allow for estimation, it remains difficult to assess the volume of trade overall. Certainly, the impact of the fish trade on the İlàje economy cannot be over-emphasized. It has been the mainstay of the people's economy and a significant bedrock for rural development at least since the

8. Ibid., 413.

9. D. O. Olubomẹin, "The Impact of Road transportation," in Hakeem Ibikunle, ed., Nigeria's Urban History: Past and Present, (Maryland: University Press of America, 2006), 45-56.

10. J. O. Adeuyan, Contributions of Yoruba People in the Economic \& Political Developments of Nigeria (Bloomington, IN: AuthorHouse, 2011), 56.

11. G. O. Oguntomisin, The Transformation of a Nigerian Lagoon Town Ėpé, 1852-1942 (Ìbàdàn: John Archers, 1999), 31.

12. Mrs. Oke, Oral Interview, 62 yrs, October 7, 2016. 
nineteenth century. Popular articles of lagoon trade in the twentieth century included fish, prawn, coconut, gàrí and cassava flour, all of which are sold in exchange for commodities from the neighboring communities of İjẹbú, Òyo, Òndó, Èkìtì, Òde-Ayé (İkálè), İbàdàn, Lagos, Onitsha, Port Harcourt and Enugu among others. ${ }^{13}$

However, an informant from İbíadé, a border town between Ògùn State and İlàjẹ in Òndó state, claims that for much of the twentieth century, Ògógóró or local gin has been the second major article of trade on the lagoon. ${ }^{14}$ Local Ogógóró consumption is high, at least since the twentieth century. ${ }^{15}$ As Ogógóró is often produced without close adherence to official processes and regulations regarding foodstuffs or drugs, it is often produced in inaccessible parts of the coastline or Delta. Its trade by water is also a means of avoiding close scrutiny of the product. Most Ògógóró trade is done in stages, from the locations of its production to nearby markets in Abígì, İwòpin, İgbògùn, or ç Omi, from where it is taken to Ẹpẹ and finally to Lagos. ${ }^{16}$

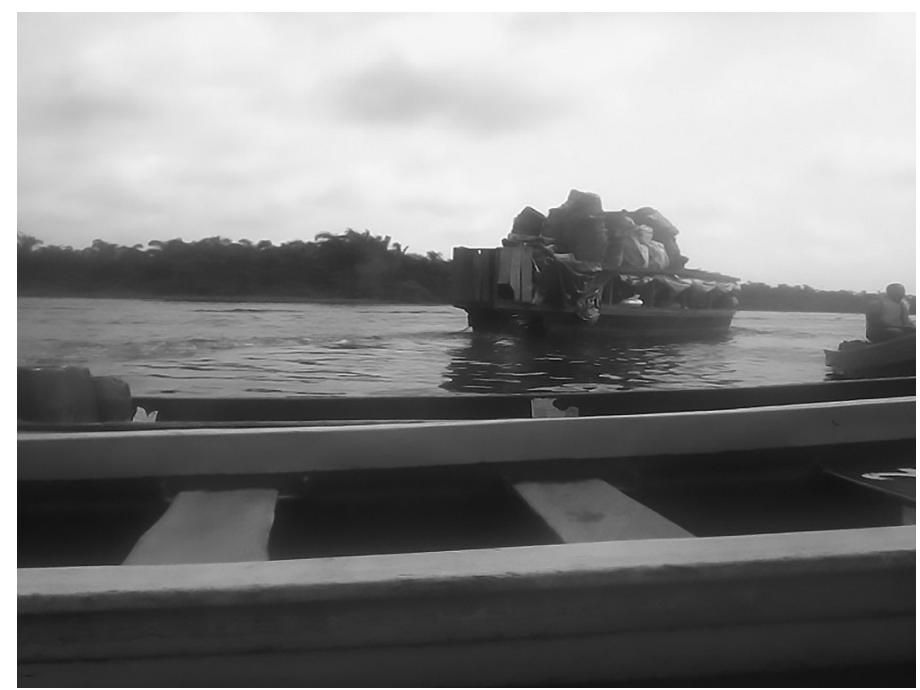

Figure 2. Canoe with a MAN Diesel Engine on the lagoon arriving at ÒdeÜgbò Wharf. Source: Author's image, November 8, 2016.

13. Personal Interview, Mrs. Oke. 62yrs. Mrs Oke has a long history of trading relations with the İlàje people dated back to 2001.

14. Adebukọla Saidat, oral interview, 60yrs, İbíadé, August 9, 2016.

15. In the second decade of the twentieth century, Lugard already referred to the high consumption of the local gin, Ògógóró, in the area. He believed it was on the increase in the region. See Adeuyan, Contributions of Yorùbá People, 56.

16. Adebukola Saidat, oral interview, 60yrs, İbíadé, August 9, 2016. 
Cassava has also been an important item of east-west trade in the twentieth century. It is usually processed into a product known as púpúrú among the İlàjẹ, and the fact that it has become the major staple food of the İlàjẹ means that it plays an important role in the coastal markets. European and locally made printed cloth is also traded regularly, though the trading networks for cloth have been transformed as many goods formerly traded by water could be transported by road. Sixty years ago, most locally traded cloth came through the İjẹbú coastal towns and by boast, but now cloth increasingly comes by road from either Òndó (Àkúrẹ́ and Òndó) or Ọyọ̣ State (İbàdàn), or from Onitsha, Owerri, Aba, and Port-Harcourt in south eastern Nigeria. This shift indicates the growing importance of national trade. Illustrating the impact of a growing global trade, Chinese wares have increasingly replaced European electrical or consumer goods over the past two decades.

\section{Fishing and Fish Preparation in İlàjẹ today}

Essentially, canoes have been fundamental to life by the water. In İlàjẹ communities, almost every traditional occupation involved the use of the canoe, and more recently the speedboat. ${ }^{17}$ In this vein, fishing has a long history in the İlàjẹ areas. Over time, a differentiation of different fishing practices has emerged. Thus there are three main forms of fish production. The first is artisanal fishery, which involved the capturing of fish by individuals or small groups for subsistence or sale, which usually requires intensive labor. Today, artisanal fishing coexists with local aquaculture and with industrial fishing.

Artisanal fishing remains very common within the Ìlàjẹ communities, possibly due to the people's long historical practice of it, but also as subsistence fishing because of financial constraints. The artisanal system relies on locally manufactured canoes, which have been improvised and modernized. Ikuejube explains that fishing instruments include Àwọ̀ (nets with hooks on which is earthworms are hanged for bait), Akașẹ or Epòrò (bamboo poles used as spears) and İyànmà (basket placed in shallows streams and fixed to the bottom of the creek with sticks). ${ }^{18}$ These have remained traditional instruments of fishing among the İlàjẹ fishing communities.

Olúkòjú claims that fresh water fishing was traditional to the İlàjẹ and was predominant until the 1950s, when different groups also embarked upon canoe fishing in the brackish water along the creeks and in the lagoons. Olúkòjú

17. Osiruemu, "Water transportation in the Niger Delta," 411-421.

18. G. Ikuejube, Ilaje: The Yorùbá Fishing People of the Niger Delta (Òndó: Novec Printer, 2005), 5-6. 
further states that in the 1960s, coastal fishing took over from fresh water productions. Because of the openness of the Atlantic coast, coastal fishing requires the use of larger canoes, and it often involved industrial fishing with fishing trawlers fitted with set-nets and other advanced equipment. ${ }^{19}$

Today, most canoes are fitted with engines, usually by Yamaha. There are different types of engines, ranging from $40 \mathrm{hp}$ to $150 \mathrm{hp} .{ }^{20}$ The category of motor chosen depends on the size of the canoe or speedboat and of course its use. Canoes that carry foodstuffs and goods from the İkálẹ to the İlàjẹ markets, from one coastal market to the other or from İlàjẹ to Lagos are bigger in size and can transport as much in volume as a 25 tons MAN Diesel lorry. These types of canoe are fitted with a MAN diesel or Mercedes 911 engine (see Figures 2 and 3). Such heavy canoes are used for both goods and passengers to and from the coastal markets.

Like canoes, speedboats serve two purposes. First, speedboats are means of transportation from one location on the coastline or lagoon to another. For

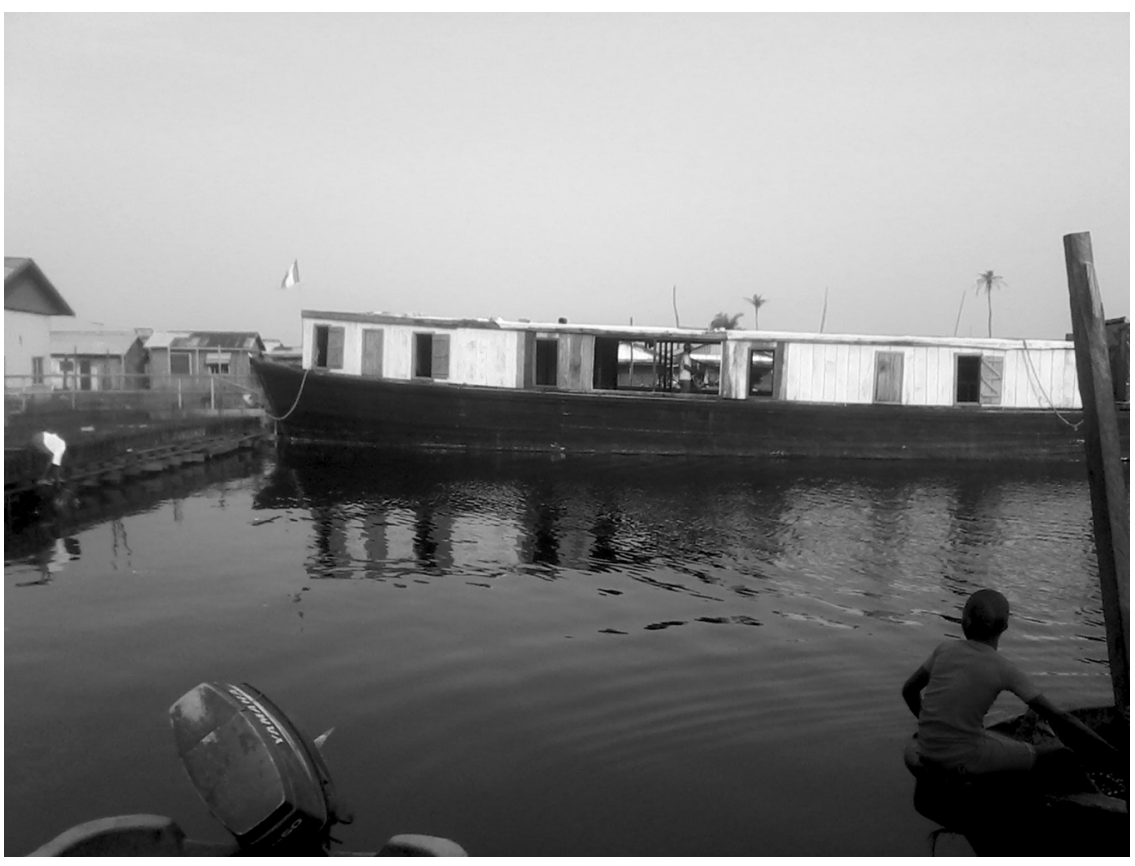

Figure 3. Boat with a MAN Diesel Engine at Ayétòrò Wharf. Source: Author's image, November 8, 2016.

19. Olukoju, "Fishing, Migration and Intergroup Relations," 69-85.

20. Hp refers to horsepower. A unit of metric horsepower equals 4,500 kilogram-meters per minute. 
example, from Ùgbò-Ńlá to Ayétòrò, a speedboat carries about twenty passengers, four in a row of five or six, excluding the anchor man. Secondly, engine-powered boats are used for fishing on the high sea. In Ayétòrò, İdíọgbá and Òkè-İdiọggbá, all communities that are located directly on the coastline, fishing done by boats fitted with Yamaha engines is prevalent. Both the locally improved canoe and the engine-powered boat have enabled the fishermen to extend their activities beyond the lagoon toward the high seas. A member of Abílógun family of Òkè-İdiọgbá explained why saltwater fishing did not rely solely on speedboats; saying that

The small and light canoes are being used due to the temper of the ocean, which could rise at any time. Thus the need for very light and flexible equipments [sic] which the fisherman could handle and control in time of [the] oceans' wave and surge. ${ }^{21}$

Traditionally, fish was consumed when it was freshly harnessed from the sea. However, if only fresh fish is sold, the profitability depends largely on high patronage. Once fish are produced in commercial quantities, it becomes diffi-

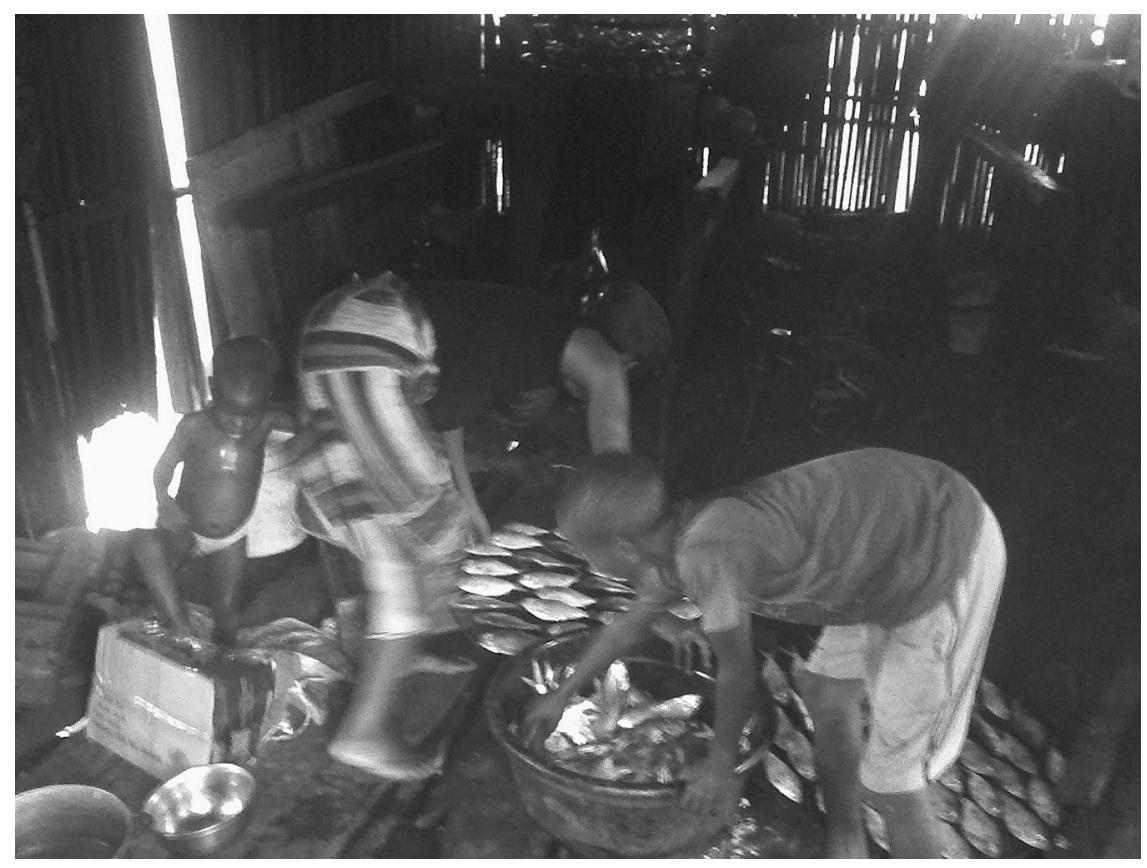

Figure 4. Fish tenting process. Source: Author's image, November 7, 2016.

21. Abilogun Oke, oral interview, 60yrs, November 6, 2016. 
cult to sell fresh fish within the short period of its suitability for consumption, which is between 12-14 hours depending on the species of fish. To circumvent this problem, various means of fish processing have been developed. The processing starts from when the fish changes hands at the coastline. Fish is first washed to prepare it for gutting, which is the removal of the intestine, and then cut in preparation for tenting, which means hanging the fish so that a large part of its surface area is exposed to the air, as if in a tent (Figure 4).

Once the fish has been tented, it is subjected to smoking over a local furnace made of drum (Figure 5). The smoking aids the removal of water from the flesh through heat, thus inhibiting the action of micro-organism and prolonging the shelf life of the fish. Smoking therefore, combines three main effects, drying, cooking and preservation. ${ }^{22}$

Like in many coastal communities in this part of the world, fishing is segmented along gender lines. The actual fishing, or fish production, is undertaken by men and male children, and a man's wife or wives and female children usually take on the processing and marketing of his fish. ${ }^{23}$ However, some fish

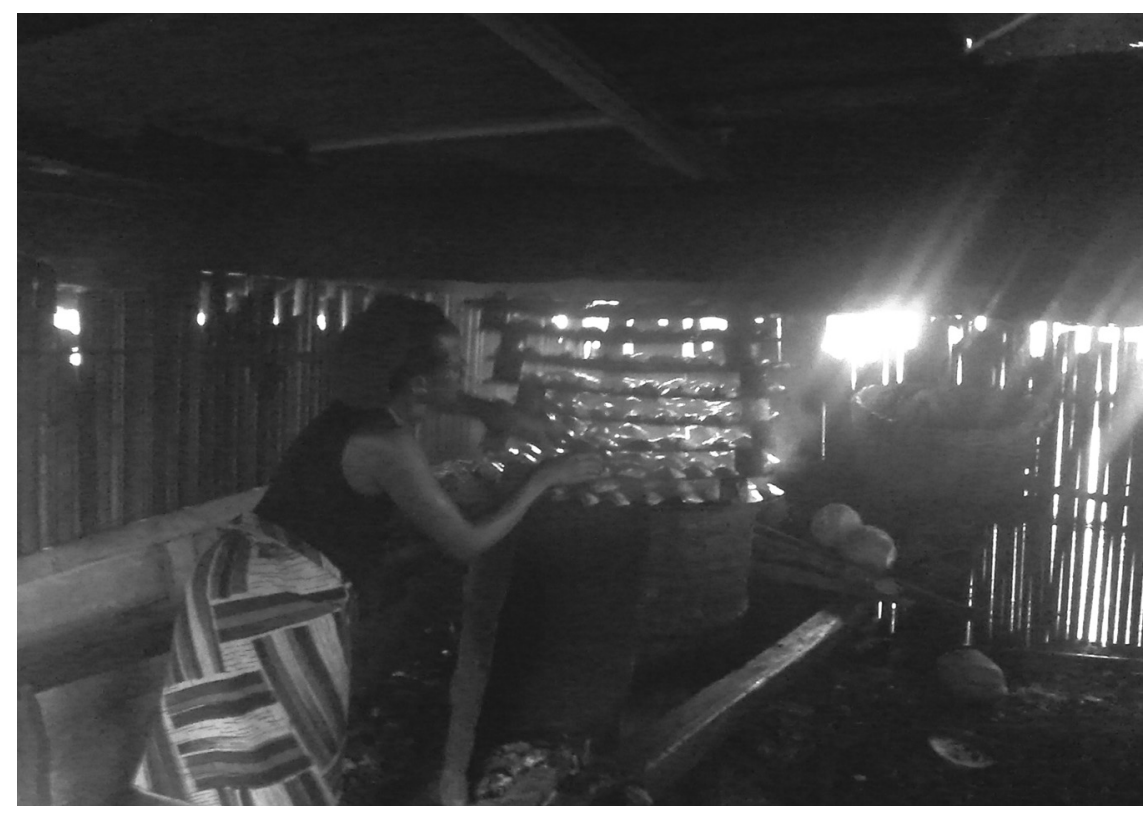

Figure 5. Fish smoking at Òkè-İdíọgbá community. Source: Author's image, November 7, 2016.

22. G.C. Rawson and F. A. Sai, A Short Guide to Fish Preservation (Rome: FAO, 1966).

23. Personal Interview, Mrs. Oke. 62yrs. Mrs Oke has a long history of trading relations with the İlàje people dated back to 2001. 
By Canoe and Speedboat: The Recent Expansion of the İlàjẹ Fishing Trade

is also sold by fishermen to businesswomen who operate on a larger scale, and then sold on - fresh or processed - in various markets. The peculiarity of the İlàjẹ environment and distribution of labor has also influenced more general traditions of social and economic behavior.

As women are the main processors and producers of fish, markets are generally under women's control. They formulate, administer rules, regulate and settle all questions on market matters, and generally exhibit a lot of zeal in the conduct of trade. ${ }^{24}$ In the Ìlàjẹ areas, the İyálọjà (these markets have bàbálọjà and Iyálọjà) remains the head of the market. The periodic nature of the markets, usually held every 9 days in the İlàjẹ area, encourages bigger markets, because local trade in the interval is limited. Also, it allows smaller communities to make preparations for traders from other regions and localities.

All markets are part of larger networks of markets, which operate one after the other. As individual markets are usually located at a day's (or at most two day's) distance from each other, such networks allow professional traders to travel between them. The traders who travel far are usually men, and in the past, they often slept in the markets, though many also develop local relationships and stay with patrons. In markets that attract long-distance traders, many articles of trade are sold that cannot not be found in daily markets, such as clothing materials, exotic foodstuffs and household materials.

\section{Road construction in the aftermath of the 1998-9 Ìlàjẹ-ljaw war}

Until the first decade of the twenty-first century, İgbọ́kọddá market was the major market in İlàjẹ. İgbọ́kọdá is probably the most central İlàjẹ town; and it is also the local government headquarters of İlàjẹ Local Government. However, İgbọ́kọ̀dá now coexists with markets at Ipárè, Òbínẹ́hìn, Arárọ̀mí, Etíkàn, Igbó-ńlá, Òkè-ńlá, Ùgbò and İsàlè-òkun. ${ }^{25}$ These markets emerged between 2009 and 2013 largely due to the construction of roads between İgbọ́kọdá and Ùgbò-Ńlá and between Àbòtó and Arárọ̀mí between 2003 and 2007. ${ }^{26}$ The Àbòtó-Arárọ̀mí road is an important trading route that links Òndó state with Ògùn state, because Arárọmí is a border town through which traders from İlàjẹ coastline to reach Atíjẹrẹ́, an important historical trade centre of the İlàjẹ.

The construction of the road that opened up İlàje for road traffic was partly the outcome of the war between the İlàjẹ and the Ijaw Àrògbò between Sep-

24. L. Olurode,. "Economic Culture," in L. Olurode, ed., Nigeria: People and Culture (Lagos: Rebork Publications, 1999), 46.

25. Personal Interview, Mrs. Oke. 62 yrs.

26. Ondo State Economic Development Strategy (SEEDS) Document (Akure: Government Printer, 2004), ix-xii. 
tember 1998 and 1999, because it was built in order to reduce the enmity and competition between the two neighboring groups. The history of the war between the Îlàjẹ and their Àrògbò Ijaw neighbors has not been well documented. The Ijaw Àrògbò group inhabit a very swampy inland part of the Niger-Delta. In the past, the Ârògbò-Ijaw were palm wine tappers and canoe builders, but long years of interaction between the İlàjẹ and the Àrògbò Ijaw people have resulted in cultural diffusion between the two groups. Some of the Ijaw now practice fishing while some İlàjẹ have adopted canoe building techniques from the Ijaw which made their occupation and products complementary.

In 1998, disagreements over the distribution of government funds for oil-producing communities erupted into a fight between the two groups. The supposed discovery of oil in Àpáta created an ownership problem. The disagreements centered on the question of which group had settled earlier and was thus the 'landlord' of the other in different locations, which meant that they would receive a larger share of government funds. The most important disagreement was over the ownership of Àpáta town, which was claimed by members of both groups. Once it became clear that the town might be eligible for 'resource control' funds, members of both groups took up arms against one another.

Eventually as the crisis escalated into serious conflict between the two groups, the violence led to the loss of human lives, the destruction of property and even the displacement of whole communities. Eventually this war affected a large number of settlements including Obè, Àwòyè, Ilẹpẹ̀tẹ̀, and Òròtò among the İlàjẹ settlements attacked by the Ijaw Àrògbò ethnic group. Many İlàje fled their towns on the coastline, easily accessible by canoe, to communities further west and inland, such as Mahin, Etíkàn, Àhérì, Ẹpẹ́, İwòpin, Òkìtìpupa, and Àkúrẹ. At one point, the Zionist town of Ayétòrò was the only coastal town left for the İlàjẹ people.

The war caused serious socio-economic challenges beyond the destruction of settlements. For instance, refugees from destroyed settlements, called bógundé (war refugees), caused population explosions in places like İgbọ́kọdá, Oríòkè-İwàmímọo, Ògógóró , Erékè, Arárọmmí and Holy Centre to mention a few of İlàjẹ communities untouched by the conflict. The influx of new entrants into these towns challenged the social and economic structure in two ways. First, it put pressure on the lagoon as larger numbers of people attempted to make a living from its wealth, and second, it increased trade and economic activities. As a result of the latter, the only existing market at İgbọ́kọdá became congested due to the increased number of traders, which created tension.

Unlike in the pre-crisis period, when middlemen moved from one Wharf (Ėbúté) to the next to purchase fish in exchange for goods, the crisis prevented these traders from gaining access to the coastal wharfs. This meant that just as 
larger numbers of people had moved to İgbộkọdá, fewer exchange commodities found their way to its market. After government intervention to end the war in 1999, the combination of scarcity and the increased demand for trade goods was felt strongly by those who had been refugees in larger urban centers. Eventually the government responded by planning and building new roads to support the re-establishment of trade in İlàjẹ.

\section{The emergence of new markets}

Since the mid-2000s, the introduction of road transportation has greatly increased the quantity of goods traded. Not only did the roads make it easier to move commodities into İlàjẹ, but they also reduced the typically long chains of intermediaries associated with trade by boat or on foot. ${ }^{27}$ The roads have reduced the time needed to move between different locations, and they have also reduced the insecurity associated with transportation on the lagoon. Since the completion of the road network, the traffic in trade has continued to increase, making a significant contribution to the socio-economic development of İlàjẹ communities and the İlàjẹ people generally.

The growing trade has been supported by the Òndó state government in different ways. In response to the pressure on the market at İgbọ́kọdá, which often resulted in parking and accommodation problems, and even occasional conflict, government renovated the market in $2012 .{ }^{28}$ The renovations made the markets more habitable and comfortable for traders and customers alike. One peculiarity in the trading culture on the coastal market was that almost all markets open from 3:00 am in the morning and close very early, usually before 3:00 pm. However, after the renovations, trade at İgbọ́kọdá was extended to very late in the evening.

The renovation also increased the capacity at İgbọkọ̀dá in other ways: many markets operate the àwàgún system, which means that non-perishable goods can only be sold when the market is officially open, which in the case of periodic markets could only be once in 4, 6 or 9 days. (Most markets in İlàje are 9-day markets, but perishables may be sold on the day of arrival.) Many markets also limit the goods that can be sold, which could be fish and ingredients like pepper, onions, and other vegetables. Once the İgbọ́kọdá market was expanded, it offered a greater choice of wares. Also, while the market officially

27. The Bàbálọjà of Òbínẹ́hìn. Mr. Adeha told us that before the establishment of Obínẹ́hìn market in 2010, they used to trek a long distance before they could get to Atijèrè market.

28. Bàbálọjà of Ùgbò market, Bàbó Òyìnbó, Oral interview, November 6, 2016, 65 years. 
remains an eight-day market some traders now display their wares, including fish, every day. This development encouraged traders and people of other ethnic groups to take up trade in these markets, and some even settled permanently within the new market areas. ${ }^{29}$ Hotels and rest houses have also sprung up to cater for the need of travelers from the east and northern part of Nigeria.

However, the renovation did not resolve all problems at İgbọ́kọdá. This had been anticipated by different parties, including the İlàjẹ Traders Union. Once the new roads into İlàjẹ had been completed, the İlàjẹ Traders Union, then based in İgbọ́kọ̀dá, sent a request to İgbọ́kọ̀dá local government to call for applications from towns that wanted to set up separate markets in their communities. Several communities submitted applications, which were, however, not processed until 2009. Keen to find a different solution, people from the settlement of Agbá (Etíkàn) went to the neighboring (İkálẹ) Òkìtìpupa local government council where they were granted permission to establish the Etíkàn market in July 2009.

In 2010, İgbọ́kọdá local government, with permission and financial support from Òndó state government, granted permission to establish Ipárè market as well as several other markets on the Àbòtó-Arárọ̀mí road. This road, which leads to Atíjẹrẹ́ market, presently accommodates about six new markets established between 2010 and 2013. Ipárè market was established in 2010, Òkè-ńlá, Òbínệhìn, Erékè, and Arárọ̀mí in 2010, Ẹránmọ̀n in 2011, and Ùgbò-Ńlá in 2013. The second new road from İgbọ́kọdá to Ügbò-Ńlá has two important markets, the first in Òde-Ügbò and the second at Ùgbò-Ńlá, which links to Ayétòrò, İdíọgbá, and İdíògún by water.

In addition to the markets established with help from local government, the rising volume of traffic also encouraged the expansion and development of independent markets in communities that wanted to raise the local standard of living. The babalọjà of Òbínẹhìn, market Mr Adéhà explained the reasons for the establishment of Òbínẹhìn market as follows,

Going to İgbọ́kọdá for all our needs was becoming very difficult particularly for the aged among us and [due to] the difficult terrain of the rivers. You cannot get anything to buy in this town except fish; for buying pepper, onion, tomato, vegetable [sic] or meat you have to visit İgbọ́kọdá. This made the leadership of the town in consultation with Òbínệhìn Youth Movement and Òbínệhìn Development Association to request for the market in 2009 [sic]. We were not supported like Ipárè and Ugbo [neighboring communities] even till now but we

29. The Igbo of eastern Nigeria settled on the bank/Ėbúté of the lagoon at the back of the market. 


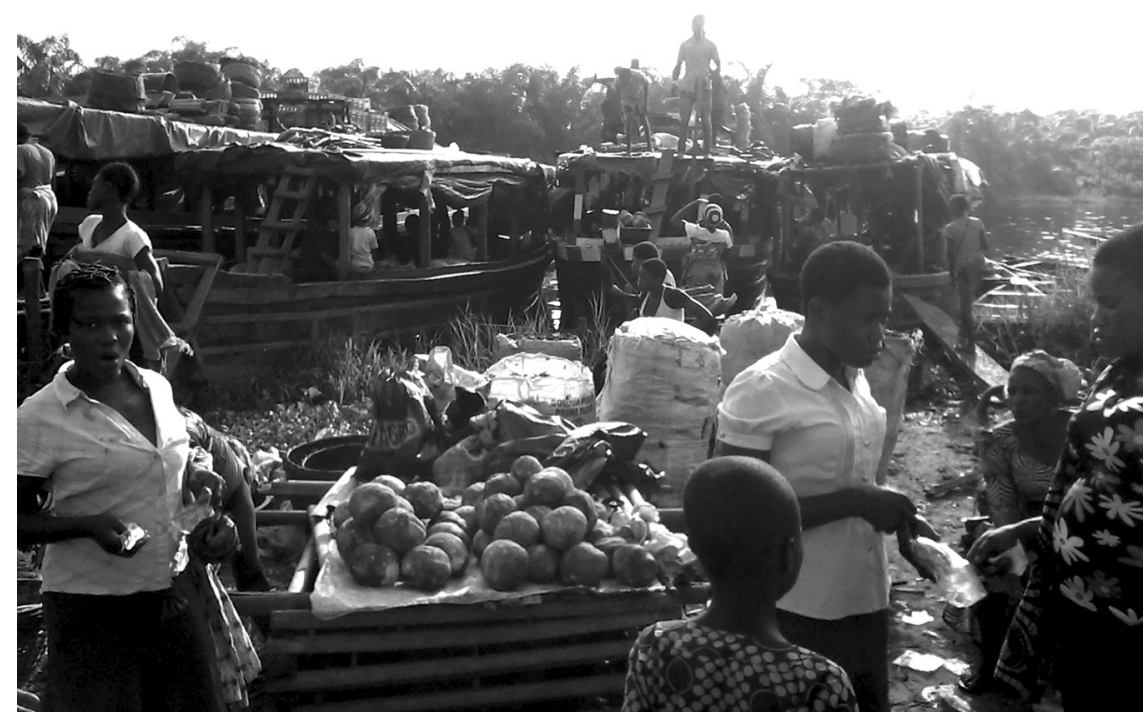

Figure 6. Òde Ùgbò Market site. Source: Author's image, November 6, 2016.

organized the leadership and the youths of the town, entered the bush to cut woods which we installed to start the market. ${ }^{30}$

Improvements to the road infrastructure have increased traders' profit margins and enabled them to make ventures into waterways that were previously financially untenable. Road transportation to Ùgbò-Ńlá for example, opens up trade to several smaller communities in the coastal areas, and draws them into regular relations of exchange. Today, on the water system, İlàjẹ traders are found hawking imported foods like bread, rice and beans, as well as clean drinking water and drugs, even to remote riverine villages. Ijaw canoe-based traders are engaged in the sale of firewood across the coastline.

As road traffic has not replaced but encouraged traffic by water by increasing profit margins on imported goods, many canoe owners have been able to modernize their fleet by building larger boats. The continuing profitability of trade by boat is also illustrated by the survival of extensive trade routes; for example, from the coastal town of Oríòè-İwàmímọ to Stone Wharf market at Òyìngbò in Lagos. There are currently four canoe transport companies that transport goods from there to Lagos. Each of the canoes has the capacity to

30. The Bàbálọ́jà of Òbínẹ́hìn, Mr Adeha, +60 yrs. 
move 25 tons worth of goods to the different market on each market day and usually accommodates about fifty passengers and forty drums (200 liters) of Ògógóró, fish, and other items such as prawn, periwinkle, and coconuts. ${ }^{31}$ Depending upon the commodities that are carried, these canoes can make the journey to Lagos in between eight and ten hours.

Oparinde and Ojo state that from the 1980s fish production has increased across the coastal region. They further explain that at least over $70 \%$ of total fish in Nigeria have been produced in İlàjẹ communities in the last two decades of the 20th century, and suggest that about 10 million people are engaged in fishing trade across the coastal belt. ${ }^{32}$ The opening up of the İlàje area to roads has further strengthened the fish trade.

Reducing middleman costs, the improvement of the transport system has enabled traders to offer more attractive terms to local producers. This in turn has encouraged an increase in production output in particular in the fishing industry. In the absence of formal systems of accounting, the high volume of trade transacted on the lagoon is only indicated by the large number of traders and vehicles, including lorries, canoes and speedboats that visit on market day.

But as most fishing is artisanal, it is also illuminating to study the income of successful artisanal fish producers. One of our informants, a fisherman who has been in the fishing trade since his youth, explained that he fishes by night to leave the day for other activities. Since fish can be caught at any time of the day, he makes sure that by midnight he is on the lagoon with the aid of a lantern or locally made lamp to set his net. He then returns by 6-7 a.m. to draw out his catch in his canoe for sale at the nearby coastal market.

Depending on the nature of the fisherman, fish is also caught in the morning, and it is usually offered for sale thrice daily at 6-7 a.m., 10-11 a.m. and 12-1 p.m. to middlemen, who in turn sell them in baskets to the marketers. Adéògo Akíntọ́lá of Òkè-İdíọgbá claimed he could make as much as three to four hundred thousand naira weekly, equivalent to two thousand dollars, from shrimps and crayfish during the peak period. The profit reduces to about 40,000-50,000 naira at off-peak period. ${ }^{33}$ This was confirmed by other fishermen. ${ }^{34}$

31. Oral interview from Mr. Aroma, Driver and Engineer on Olá-Olúwa Transport company from Orí-Òkè-ìwàmímọ́.

32. Lawrence Oluṣola Oparinde and Sylvester Oluwadare Ojo, "Structural Performance of Artisanal Fish Marketing in Òndó State, Nigeria," American Journal of Rural Development, 2 (2014): 1-7.

33. Adeogo Akintọla, oral interview, Òkè-ìdí ọgbá via Ayétòrò, 65yrs.

34. Abilogun Snr, oral interview, Òkè-ìdí ọgbá, via Ayétòrò, 73yrs. 


\section{Conclusion}

The emergence of new markets in İlàjẹ resulted from the conflicting challenges that faced the İlàje during and after the 1998-99 war with the Ijaw. Because fish traders and fishermen were no longer able to conduct business at the local wharfs, and because of refugee movements following the destruction of some coastal communities, the existing İgbọ́kọdá market became overcrowded. As access to imported goods became difficult for Ìlàjẹ residents, the government invested in road construction in order to support trade intro and out of the area.

However, road construction did not simply provide a substitute for water travel, but it provided an important economic stimulus on its own. Because transport costs declined, profit margins went up and trade greatly increased. As new markets were set up to cope with the growing volume of trade, and the growing demand of local populations who had encountered new goods while they were war refugees, some trade routes that were previously unprofitable became attractive. As canoe- and boat-based traders plied new routes and upgraded their vessels, trade on the waterways did not decline. Finally, fishermen themselves also benefited from greater profit margins and increased their productivity.

Even so, much remains to be done to improve the situation further. Many new markets do not have enough space for car and lorry parks, and apart from Ipárè, no market has health facilities - not even İgbọ́kộdá. Security also needs to be improved further, because new markets constructed in places like Òbínẹ́hìn, Ipárè and Òkè-ńlá have attracted patronage from far and near. While local visitors understand the dangers of the terrain, markets must also reduce their vulnerability to criminals who move either by boat or by car. Finally, the increased attractiveness of modernized water transportation needs proper monitoring in terms of security and safety. Life jackets should be provided to the lagoon traders as this will enhance safety of traders and goods on the lagoon. As access to electricity has remained a problem in the area, except by generator, the problem of storage could be improved once communities are linked to the national grid.

\section{Bibliography}

Falola, Toyin, and Akinwumi Ogundiran. Precolonial Nigeria: Essays in honor of Toyin Falola. Africa World Press, 2005.

Ikuejube, 'Gbade. Ilaje: The Yorùbá Fishing people of the Niger Delta. Òndó: Novec Printer, 2005.

Oguntomisin, G. O. The Transformation of a Nigerian Lagoon Town Ẹpẹ 18521942. İbàdàn: John Archers, 1999. 
Olurode, Lai (ed.) Nigeria: People and Culture. Lagos: Rebork Publications, 1999. 